Andrzej Sakowicz

Uniwersytet w Białymstoku

sakowicz@uwb.edu.pl

\title{
Glosa
}

\section{do wyroku Trybunału Sprawiedliwości Unii Europejskiej \\ z dnia 29 czerwca 2016 r. w sprawie C-486/14, Postępowanie karne przeciwko Piotrowi Kossowskiemu}

Zasadę ne bis in idem, zawarta $w$ art. 54 Konwencji wykonawczej do Układu $z$ Schengen, odczytywana $w$ świetle art. 50 Karty Praw Podstawowych, należy interpretować $w$ ten sposób, że postanowienie prokuratora kończace postępowanie karne i umarzajace prawomocnie - $z$ zastrzeżeniem wznowienia postępowania lub uchylenia postanowienia - postępowanie przygotowawcze prowadzone przeciwko osobie, przy czym nie została nałożona kara, nie może zostać uznane za prawomocne orzeczenie w rozumieniu tych artykułów, jeżeli z uzasadnienia tego postanowienia wynika, że rzeczone postępowanie zostało umorzone bez przeprowadzenia szczegótowego postępowania przygotowawczego, przy czym brak przesłuchań pokrzywdzonego i ewentualnego świadka moga wskazywać na brak takiego postępowania przygotowawczego.

1. Orzeczenie Trybunału Sprawiedliwości Unii Europejskiej (dalej: Trybunał) w sprawie C-486/14, Postępowanie karne przeciwko Piotrowi Kossowskiemu jest kolejną wypowiedzią na temat prawomocnego umorzenia postępowania karnego w kontekście funkcjonowania zasady ne bis in idem w Unii Europejskiej. Przepis art. 54 Konwencji wykonawczej do Układu z Schengen (KWUS) wskazuje, że zasada ne bis in idem stanowi środek ochrony jednostki przed ewentualnymi nadużyciami ze strony państwa w zakresie przysługującego mu ius puniendi oraz możliwości stawiania zarzutu na tej samej podstawie prawnej. Wyraża ona nie tylko charakter materialnoprawny w myśl zasady nemo debet bis puniri (albo ne bis poena in idem), czyli zakazu ponownego karania za ten sam czyn, lecz także zakłada barierę do ponownego wszczęcia postępowania w tej samej sprawie przeciwko temu samemu oskar- 
żonemu. Pozwala to uznać, że zasada ne bis in idem na podstawie art. 54 Konwencji Wykonawczej ma charakter procesowy oraz pozostaje w bliskim związku z trzema wartościami, tj. wolnością, bezpieczeństwem i sprawiedliwością, stanowiącymi podstawę budowanego jednolitego obszaru prawnego. Na ile analizowana zasada powiązana jest ze wszystkimi wartościami łącznie, a na ile z osobna, uzależnione jest od położenia akcentu aksjologicznego. W dotychczasowym orzecznictwie zaakcentowano wyraźnie, że ratio legis przepisu art. 54 Konwencji Wykonawczej jest „zapewnienie, by nikt nie był ścigany za te same czyny w kilku państwach członkowskich z powodu korzystania z prawa do swobodnego przemieszczania się" ${ }^{1}$. Nietrudno zauważyć, że prawo do swobodnego przepływu osób będzie tylko wówczas zagwarantowane, gdy osoba, wobec której postępowanie karne zakończyło się prawomocnym orzeczeniem, zyska możliwość swobodnego przemieszczania się w ramach obszaru Schengen, nie obawiając się ścigania w innym państwie za ten sam czyn zabroniony². Można więc rzec, iż przepis art. 54 Konwencji Wykonawczej pełni funkcję gwarancyjną, urzeczywistniającą osiągnięcie powyższego celu. Stanie się to jednak możliwe wówczas, gdy orzeczenia organów sądowych innego państwa członkowskiego będą traktowane jak własne, a procedura związana $\mathrm{z}$ uznaniem oraz wykonaniem tej decyzji będzie pozbawiona formalizmu ${ }^{3}$. Nie można jednak nie zauważyć, że w nowszym orzecznictwie Trybunał odwołuje się do bezpieczeństwa prawnego, zgodnie z którym zapewnia się obywatelom UE przestrzeń wolności, bezpieczeństwa i sprawiedliwości bez granic wewnętrznych, w której zagwarantowana jest swoboda przepływu osób, w powiązaniu z właściwymi środkami w odniesieniu do kontroli granic zewnętrznych, azylu, imigracji, jak również zapobiegania i zwalczania przestępczości. Mając na względzie treść normatywną wyrażona w art. 3 ust. 2 TUE oraz art. 67 ust. 3 TFUE, Trybunał w sprawie Spasic stwierdził, że zasada ne bis in idem ustanowiona w art. 54 KWUS „ma na celu nie tylko uniknięcie w przestrzeni wolności, bezpieczeństwa i sprawiedliwości bezkarności osób skazanych w Unii prawomocnym wyrokiem karnym, lecz również zagwarantowanie bezpieczeństwa prawnego poprzez poszanowanie orzeczeń organów publicznych, które stały się prawomocne, wobec braku harmonizacji lub zbliżenia przepisów prawa karnego państw członkowskich"4. Widoczne jest to na przykładzie szeregu orzeczeń Trybunału w przedmiocie art. 54 KWUS $^{5}$ dotyczących rozstrzygnięć kończących postępowanie karne przed skierowaniem sprawy do sądu. I tak, warto tylko przypomnieć, że:

1
Wyrok ETS z dnia 11 lutego 2003 r. w sprawie Gözütok i Brügge (C-187/01 i C-385/01), Zb. Orz. s. l-1345, pkt 38. Zob. wyrok ETS z dnia 9 marca 2006 r. w sprawie van Esbroeck (C-436/04), pkt 34; wyrok ETS z dnia 28 września 2006 r. w sprawie Van Straaten (C-150/05), pkt 46.

Zob. K. Ligeti: Rules on the Application of ne bis in idem in the EU. Is Further Legislative Action Required?, Eucrim 2009, nr 1-2, s. 38

Wyrok TS z dnia 27 maja 2014 r. (C-129/14 PPU) Postępowanie karne przeciwko Zoran Spasic, pkt. 77; wyrok TS z dnia 10 marca 2005 r. w sprawie C-469/03 Miraglia, Zb.Orz. s. I-2009, pkt. 25; por. też M. Wasmeier, Ne bis in idem and the Enforcement Condition, New Journal of European Criminal Law 2014, Vol. 5, Issue 4, 541-542.

Wyroki: z dnia 11 lutego 2003 r. w sprawach połączonych C-187/01 i C-385/01 Gözütok i Brügge, Rec. s. I-1345; z dnia 10 marca 2005 r. w sprawie C-469/03 Miraglia, Zb.Orz. s. I-2009; z dnia 28 września 2006 r. w sprawie 
a) w sprawie Miraglia Trybunał uznał, że orzeczenie sądu, które zostało wydane bez rozstrzygnięcia sprawy co do meritum, nie stanowi zakończenia procesu danej osoby wydaniem prawomocnego wyroku w rozumieniu art. 54 KWUS, a tym samym nie wyklucza kontynuowania postępowania karnego w innym państwie członkowskim ${ }^{6}$;

b) w sprawie Gasparini i inni Trybunał podkreślił, że zasadę ne bis in idem stosuje się do orzeczenia organu sądowego umawiającego się państwa, wydanego $\mathrm{w}$ następstwie przeprowadzonego postępowania karnego, w wyniku którego postępowanie karne wobec oskarżonego zostało prawomocnie umorzone $\mathrm{z}$ powodu przedawnienia przestępstwa objętego ściganiem ${ }^{7}$;

c) w sprawie Turanský wskazano, że postanowienie o zawieszeniu postępowania karnego wydane zanim podejrzanemu przedstawiono zarzuty, nie wyłącza wszczęcia nowego postępowania karnego o te same czyny; postanowienie o zawieszeniu nie stanowi zakończenia procesu wydaniem prawomocnego wyroku, uzasadniającego zastosowanie zasady ne bis in idem ${ }^{8}$ oraz

d) w sprawie $M$. Trybunał stwierdził, że przepis art. 54 KWUS należy interpretować w ten sposób, iż postanowienie o umorzeniu postępowania przygotowawczego i nieprzekazaniu sprawy do sądu orzekającego o odpowiedzialności karnej - które to postanowienie w umawiającym się państwie, w którym zostało ono wydane, stanowi przeszkodę dla ponownego ścigania w odniesieniu do tych samych czynów osoby, wobec której wydano owo postanowienie, chyba że ujawnią się nowe dowody uprawdopodobniające popełnienie przestępstwa przez tę osobę - należy uważać za orzeczenie stanowiące prawomocny wyrok w rozumieniu tego artykułu i stanowiące w konsekwencji przeszkodę dla ponownego ścigania tej samej osoby w odniesieniu do tych samych czynów w innym umawiającym się państwie 9 .

Każde $\mathrm{z}$ tych orzeczeń zapadło nie tylko w odmiennym układzie procesowym, lecz także w różnych uwarunkowaniach normatywnych poszczególnych państw członkowskich. Jednak brak w niektórych państwach członkowskich określonych rozwiązań normatywnych bądź istniejące różnice w zakresie ich kształtu (np. co do możliwości wznowienia postępowania zakończonego prawomocnym orzeczeniem)

C-467/04 Gasparini i in., Zb.Orz. s. I-9199; z dnia 28 września 2006 r. w sprawie C-150/05 Van Straaten, Zb.Orz. s. I-9327; z dnia 11 grudnia 2008 r. w sprawie C-297/07 Bourquain, Zb.Orz. s. I-9425; z dnia 22 grudnia 2008 r. w sprawie C-491/07 Turanský, Zb.Orz. s. I-11039.

$6 \quad$ Wyrok TS z dnia 10 marca 2005 r. w sprawie C-469/03 Miraglia, Zb.Orz. s. I-2009;

7 Wyrok TS z dnia 28 września 2006 r. w sprawie C-467/04 Gasparini i in., Zb.Orz. s. I-9199;

$8 \quad$ Wyrok TS z dnia 22 grudnia 2008 r. w sprawie C-491/07 Turanský, Zb.Orz. s. I-11039.

9 Wyrok TS z dnia 5 czerwca 2014 r. w sprawie C-398/12 M., Zb. Orz. s. I-1057; zob. szerzej B. Nity-Światłowskiej, Prawomocność orzeczenia jako element wyznaczający zakres zasady ne bis in idem w art. 54 Konwencji wykonawczej z Schengen, Europejski Przegląd Sądowy 2014, nr 5, s. 23-30; Na temat interpretacji pojęcia „prawomocny wyrok" zob. też B. Nita, Orzeczenia uruchomiające zakaz wynikający z zasady ne bis in idem w art. 54 Konwencji Wykonawczej z Schengen, Przegląd Prawa Europejskiego i Międzynarodowego 2008, nr 1, s. 6 i n.; A. Sakowicz, Zasada ne bis in idem w prawie karnym, Białystok 2011, s. 361-406 oraz podana tam literatura i orzecznictwo. 
nie mogą rzutować negatywnie na sytuację prawną jednostki. Nie mogę też oddziaływać negatywnie na skuteczność środków służących zapobieganiu i zwalczaniu przestępczości. Potwierdził to Trybunał w sprawie C-486/14 dodając, że wykładnia prawomocności orzeczenia $\mathrm{w}$ rozumieniu art. 54 KWUS powinna zostać dokonana „W świetle nie tylko konieczności zagwarantowania swobody przemieszczania się osób, ale także konieczności wspierania zapobiegania i zwalczania przestępczości w przestrzeni wolności, bezpieczeństwa i sprawiedliwości” ${ }^{10}$. Rzecz jednak w tym, że w glosowanym wyroku Trybunał poddał analizie nie instytucję prawa krajowego w kontekście ustalania prawomocności orzeczenia użytego w art. 54 KWUS, lecz ocenił jej charakter w kontekście przeprowadzonych czynności dowodowych w ramach postępowania przygotowawczego.

2. Uwagi krytyczne pod adresem wyrażonej na wstępie tezy oraz powyższego sposobu myślenia Trybunału należy poprzedzić zwięzłym nawiązaniem do stanu faktycznego, na tle którego pojawiła się wątpliwość objęta pytaniem prejudycjalnym, prowadzącym do wydania wyroku w sprawie C-486/14. Sprawa zaczęła się od tego, że prokuratura w Hamburgu zarzuciła podejrzanemu popełnienie w dniu 2 października 2005 r. w Hamburgu czynów zakwalifikowanych w prawie niemieckim jako wymuszenie rozbójnicze, jednak podejrzany zbieg z terytorium Niemiec. Został on zatrzymany na terytorium Polskim w dniu 20 października 2005 r. podczas kontroli drogowej z uwagi na oczekujący do wykonania wobec niego prawomocny wyrok skazujący na karę pozbawienia wolności. Jednocześnie prokuratura w Polsce wszczęła wobec podejrzanego postępowanie przygotowawcze o wymuszenie rozbójnicze $\mathrm{z}$ art. 282 polskiego kk. w związku z czynami popełnionymi przez niego w Hamburgu w dniu 2 października 2005 r. Mimo przekazanych dokumentów w drodze pomocy prawnej, w grudniu 2006 r. Prokuratura Rejonowa w Kołobrzegu przekazała prokuraturze w Hamburgu postanowienie $\mathrm{z}$ dnia 22 grudnia 2006 r. o umorzeniu postępowania karnego przeciwko podejrzanemu z powodu braku danych dostatecznie uzasadniających podejrzenie popełnienia przestępstwa. Postanowienie zostało uzasadnione tym, że podejrzany odmówił składania wyjaśnień, a pokrzywdzony w sprawie w postępowaniu głównym oraz świadek według pogłosek mieszkali w Niemczech, dlatego nie mogli zostać przesłuchani w toku postępowania przygotowawczego, a zatem informacje pokrzywdzonego - częściowo niedokładne i sprzeczne - nie mogły zostać zweryfikowane. Jednocześnie sąd pytający dodał, że - według pouczenia o przysługujących środkach zaskarżenia dołączonego do postanowienia kończącego postępowanie karne - zainteresowanym stronom przysługiwało prawo wniesienia zażalenia w terminie 7 dni od daty doręczenia tego postanowienia. Wartym podkreślenia jest to, że w dniu 24 lipca 2009 r. prokuratura w Hamburgu wydała europejski nakaz aresztowania podejrzanego, po uzyskaniu w dniu 9 stycznia 2006 r. krajowego 
postanowienia o aresztowaniu podejrzanego wydanego przez Amtsgericht Hamburg (sąd rejonowy w Hamburgu), jednak Sąd Okręgowy w Koszalinie postanowieniem z dnia 17 września 2009 r. odmówił wykonania europejskiego nakazu aresztowania ze względu na istnienie postanowienia kończącego postępowanie karne, wydanego przez Prokuratora Rejonowego w Kołobrzegu, które sąd ten uznał za prawomocne w rozumieniu kodeksu postępowania karnego. Pomimo to, w dniu 7 lutego 2014 r. P. Kossowski, nadal poszukiwany w Niemczech, został zatrzymany w Berlinie, zaś w marcu 2014 r. prokuratura w Hamburgu sporządziła przeciwko niemu akt oskarżenia. Landgericht Hamburg odmówił wszczęcia postępowania sądowego, uzasadniając swoją decyzję wygaśnięciem prawa oskarżyciela do oskarżania w rozumieniu art. 54 KWUS, ze względu na umorzenie postępowania przygotowawczego w sprawie o wymuszenie rozbójnicze w Polsce. W konsekwencji, postanowieniem z dnia 4 kwietnia 2014 r. sąd ten uchylił nakaz aresztowania wobec podejrzanego, który został zwolniony z aresztu tymczasowego, gdzie został wcześniej umieszczony. Sąd pytający, tj. Hanseatisches Oberlandesgericht Hamburg, do którego prokuratura w Hamburgu odwołała się od tego postanowienia, uznał, że według prawa niemieckiego stopień podejrzenia popełnienia czynu przez podejrzanego jest wystarczający, by uzasadnić wszczęcie postępowania sądowego przed Landgericht Hamburg i dopuścić akt oskarżenia, chyba że stoi temu na przeszkodzie zasada ne bis in idem wyrażona w art. 54 KWUS i art. 50 KPP. Mając na względzie powyższe wątpliwości, sąd pytający postanowił wystąpić z pytaniem prejudycjalnym, czy zastrzeżenie zgłoszone przez Republikę Federalną Niemiec na podstawie art. 55 ust. 1 lit. a KWUS nadal obowiązuje oraz czy zawartą w art. 54 KWUS i art. $50 \mathrm{KPP}$ zasadę ne bis in idem należy interpretować $\mathrm{w}$ ten sposób, że sprzeciwia się ona ściganiu podejrzanego w jednym państwie członkowskim, gdy postępowanie karne wszczęte przeciwko tej osobie w innym państwie członkowskim zostało umorzone przez prokuraturę - bez wykonania obowiązków nałożonych tytułem sankcji i bez szczegółowego postępowania przygotowawczego ze względów faktycznych w wyniku braku dostatecznie uzasadnionego podejrzenia popełnienia czynu i może być ponownie wszczęte tylko wtedy, gdy stały się znane istotne, wcześniej nieznane okoliczności, przy czym jednak takie nowe okoliczności nie mają miejsca w niniejszej sprawie?

Trybunał Sprawiedliwości uznał, że „postanowienie kończące postępowanie karne, takie jak w sprawie w postępowaniu głównym, wydane w sytuacji, gdy oskarżyciel publiczny odstąpił od oskarżenia publicznego wyłącznie z tego powodu, że podejrzany odmówił składania wyjaśnień, a pokrzywdzony i świadek według pogłosek zamieszkiwali w Niemczech, a zatem nie mogli zostać przesłuchani w trakcie postępowania przygotowawczego i twierdzenia pokrzywdzonego nie mogły zostać zweryfikowane, bez przeprowadzenia żadnego bardziej szczegółowego postępowania przygotowawczego w celu zgromadzenia i zbadania dowodów, nie stanowi rozstrzy- 
gnięcia poprzedzonego oceną sprawy co do istoty"11. Zdaniem Trybunału zastosowanie art. 54 KWUS do tego rodzaju rozstrzygnięcia skutkowałoby utrudnieniem, a nawet stanowiłoby przeszkodę dla jakiejkolwiek konkretnej możliwości ukarania w zainteresowanych państwach członkowskich bezprawnego zachowania zarzucanego podejrzanemu. $Z$ jednej strony wspomniane postanowienie o umorzeniu postępowania zostałoby wydane przez organy wymiaru sprawiedliwości jednego państwa członkowskiego bez jakiejkolwiek szczegółowej oceny bezprawnego zachowania zarzucanego podejrzanemu. $Z$ drugiej strony wszczęcie postępowania karnego o te same czyny w innym państwie członkowskim stałoby się problematyczne, gdyż tego rodzaju skutek byłby sprzeczny - jak dodał Trybunał - z samym celem art. 3 ust. 2 TUE, o którym była mowa powyżej.

3. Rację ma Trybunał, że zastosowanie zasady ne bis in idem w związku z orzeczeniem wydanym w jednym z państw członkowskich może skutkować wyłączeniem ścigania w innym państwie członkowskim, nawet w sytuacji gdy sądy drugiego państwa członkowskiego mogły dojść do odmiennych wniosków na podstawie zasadniczo tych samych faktów lub dowodów. Taki stan rzeczy nie dziwi. Stanowi on konsekwencję braku harmonizacji przepisów w obszarze prawa karnego, o czym trzeba pamiętać przy wyciąganiu wniosków z analizy poszczególnych orzeczeń Trybunału w zakresie zasady ne bis in idem. Zresztą, jak trafnie wskazał we wcześniejszych judykatach Trybunał, „żadne postanowienie tytułu VI Traktatu o Unii Europejskiej, dotyczącego współpracy policyjnej i sądowej w sprawach karnych, którego art. 34 i 31 stanowiły podstawę prawną art. 54-58 KWUS, ani układ z Schengen czy sama KWUS nie uzależniają zastosowania art. 54 KWUS od harmonizacji lub co najmniej zbliżenia ustawodawstw karnych państw członkowskich w zakresie terminów przedawnienia ścigania z oskarżenia publicznego" ${ }^{12}$. Słusznie wskazuje zatem rzecznik generalny Y. Bota, że zasada ne bis in idem, posiadająca obecnie charakter fundamentalny jako warunek praktycznego stosowania swobody przepływu, wymaga w rzeczywistości, aby państwa członkowskie darzyły się wzajemnym zaufaniem. Różnice ustawodawstw krajowych nie mogą stanowić przeszkody w obowiązywaniu tej zasady. Wszak nawet Traktat o funkcjonowaniu UE wyraża podstawę prawną zbliżenia ustawodawstw wyłącznie w celu ułatwienia funkcjonowania mechanizmu wzajemnego uznawania. To właśnie poprzez zastosowanie zasady wzajemnego uznawania prawodawca unijny zamierzał przezwyciężyć problemy, zdawałoby się nie do przezwyciężenia, ze względu na trudności szerszego zbliżenia ustawodawstw krajowych. Stosowanie zasady wzajemnego uznawania nakłada na państwa członkowskie obowiązek wzajemnego darzenia się zaufaniem niezależnie od różnic w ich odpowiednich ustawodawstwach krajowych, co szczególnie widoczne jest na przykładzie zasady ne bis in

11 Wyrok TS z dnia 29 czerwca 2016 r. w sprawie C-486/14, pkt 48.

12 Wyrok TS z dnia 11 lutego 2003 r. w sprawach połączonych C-187/01 i C-385/01 Gözütok i Brügge, Zb. Orz. s. I-1345, pkt 32; wyrok TS z dnia 9 marca 2006 r. w sprawie C-436/04 Van Esbroeck, Zb. Orz. str. I-2333, pkt 29. 
idem ujętej w przepisie art. 54 KWUS. Założenie to jest prawidłowe. Pozwala bowiem na urzeczywistnienie gwarancji wynikających z zasady ne bis in idem, mimo istnienia różnic między systemami prawnymi państw członkowskich np. w zakresie rozumienia pojęcia „prawomocny wyrok” (w polskiej wersji językowej), występującego w innych wersjach językowych jako np. rechtskräftig Abgeurteilt w wersji niemieckiej, définitivement jugée - w wersji francuskiej, czy - w wersji holenderskiej - bij onherroepelijk vonnis. Zakres przedmiotowy tych pojęć budzi liczne spory doktrynalne, w większości wynikające $\mathrm{z}$ próby odczytywania pojęcia konwencyjnego poprzez odwołanie się do przepisów krajowych ${ }^{13}$. Tymczasem, jak słusznie wskazała najwyższa instancja sądowa w UE w sprawach połączonych Gözütok i Brügge ${ }^{14}$, zasada ne bis in idem „zakłada, iż pomiędzy państwami członkowskimi istnieje wzajemne zaufanie co do systemów sądownictwa karnego i że każde z tych państw akceptuje stosowanie prawa karnego obowiązującego w innych państwach członkowskich, nawet jeśli zastosowanie własnego prawa krajowego prowadziłoby do innego rozwiązania"15. Inaczej mówiąc, możliwość odmiennego rozstrzygnięcia sprawy jest konsekwencją faktu braku harmonizacji.

Spostrzeżenie to powinno znaleźć zastosowanie do rozstrzygnięcia kończącego postępowanie $\mathrm{w}$ fazie in personam prokuratorskim postanowieniem o jego umorzeniu ze względu na brak dowodów. Trzeba wyraźnie powiedzieć - wbrew stanowisku Trybunału - że prawomocność takiego postanowienia (o ile jest przewidziana przez prawo krajowe) nie jest uzależniona od tego, czy postępowanie przygotowawcze zostało przeprowadzone szczegółowo, czy został przesłuchany pokrzywdzony bądź wszyscy świadkowie. Przyjęcie poglądu wyrażonego w glosowanym orzeczeniu oznaczałoby, że gwarancje wynikające $\mathrm{z}$ zasady ne bis in idem byłyby uzależnione od oceny prowadzonych czynności dowodowych w ramach postępowania przygotowawczego przez organ innego państwa członkowskiego. Nie ulega jednak wątpliwości, że taka ocena pozostaje w opozycji do wzajemnego zaufania między państwami członkowskimi, podważa sens zasady wzajemnego uznawania oraz kłóci się z ideą przestrzeni wolności, bezpieczeństwa i sprawiedliwości. W tym kontekście trzeba stwierdzić, że nie może nastąpić uzależnienie uznania orzeczenia organów wymiaru sprawiedliwości jednego państwa członkowskiego przez organy drugiego państwa od tego, że w jednym państwie zapada ono na etapie postępowania prokuratorskiego, a w innym - sądowego. Z uwagi na różnorodność systemów prawnych państw członkowskich UE, musi nastąpić powiązanie zasady ne bis in idem z przedmiotem sprawy i osobą sprawcy, a nie z organem wydającym orzeczenie. Trafnie wskazał Sąd Naj-

13 Por. R.M. Kniebühler, Transnationales „ne bis in idem”, s. 176-190; A. Eicker, Transstaatliche Strafverfolgung. Ein Beitrag zur Europäisierung, Internationalisierung und Fortentwicklung des Grundsatzes ne bis in idem, St. Gallen-Harbolzheim 2004, s. 159-167; J.-F. Bohnert, O. Lagodny, Art. 54 SDÜ im Lichte der nationalen Wiederaufnahmegründe - Zugleich Besprechung von BGH, Urteil vom 10. 6. 1999 - 4 StR 87/98, Neue Zeitschrift für Strafrecht 2000, Heft 12, s. 638-639.

14 Wyrok ETS z dnia 11 lutego 2003 r. w sprawie Gözütok i Brügge (C-187/01 i C-385/01), Zb. Orz. s. I-1345, pkt 33.

15 Wyrok ETS z dnia 11 lutego 2003 r. w sprawie Gözütok i Brügge (C-187/01 i C-385/01), Zb. Orz. s. I-1345. 
wyższy w orzeczeniu z dnia 2 czerwca 2006 r. $^{16}$, że państwo musi uznać wyniki postępowania karnego w innych państwach, nawet jeśli różnią się one od wyników postępowania prowadzonego w oparciu o własne prawo karne. Zrozumiałą kwestią jest, że mogą wystąpić różnice w systemach prawnych, a ewentualne próby ich pokonania okażą się daremne. Nie mogą one jednak rzutować na realizację zasady ne bis in idem oraz poszanowanie praw jednostki. Trzeba przy tym podkreślić, że zaufanie oznacza swoiste domniemanie, które pozwala dojść do określonej konkluzji procesowej czy też zaufanie do decyzji funkcjonariuszy wymiaru sprawiedliwości, bądź - jak wolą niektórzy - przypuszczenie, że systemy wymiaru sprawiedliwości we wszystkich państwach członkowskich spełniają minimalny standard ochrony praw człowieka, wyznaczony przez EKPCz wraz z protokołami i dynamicznym orzecznictwem strasburskim ${ }^{17}$. Do ostatniego ujęcia zasady wzajemnego zaufania nawiązał lord Bingham w Dabas v. High Court of Justice in Madrid twierdząc, że państwa członkowskie UE dzielą wspólne wartości i uznają wspólne prawa, a zatem nic nie stoi na przeszkodzie, aby mogły nawzajem zaufać sprawiedliwości (fairness of each other's judicial institutions) organów sądowych ${ }^{18}$. Chodzi przy tym o zaufanie, na którym może oprzeć się wzajemne uznawanie reconnaissance de plein droit, ipso iure, czyli zakazujące „wartościowania” systemu wymiaru sprawiedliwości państwa skazania przez organy państwa wykonania, prowadzące do wykazania zbędności procedury exequatur oraz zredukowania podstaw odmowy wykonania czynności opartej na określonym instrumencie współpracy w sprawach karnych. Aby tak jednak się stało, wzajemne uznawanie powinno przejawiać wzajemne zaufanie do systemów prawnych oraz czynności prawnych ${ }^{19}$, a zatem nawiązywać istotowo do anglosaskiej comity oraz ekstradycyjnej zasady non-inquiry, zgodnie z którą sąd państwa wezwanego nie może badać procesu wydania wniosku ekstradycyjnego ${ }^{20}$.

Wyrok SN z dnia 2 czerwca 2006 r., IV KO 22/05, OSNKW 2006, nr 7-8, poz. 75.

Zob. G . de Kerchove, A. Weyembergh (eds): La confiance mutuelle dans l'espace penal européen/Mutual Trust in the European Criminal Area, Editions de L'Universite de Bruxelles, Bruxelles 2005, passim; S. Peers: Mutual recognition and criminal law in the European Union: Has the Council got it wrong?', 41 CMLR 2004, Vol. 41, s. 5; V. Mitsilegas: The constitutional implications of mutual recognition in criminal matters in the EU, CMLR 2006, Vol. 43, s. 1277; M. Fichera, Ch. Janssens: Mutual recognition of judicial decisions in criminal matters and the role of the national judge, „ERA Forum” 2007, Vol. 8, s. 177.

Zob. wyrok Court of Appeal of England and Wales, w sprawie Dabas v. High Court of Justice in Madrid $z$ dnia 28 lutego 2007 r., [2007] UKHL 6; AC 31, para 4. Stwierdza się w niej, że „The important underlying assumption of the Framework Decision is that member states, sharing common values and recognising common rights, can and should trust the integrity and fairness of each other's judicial institutions". W innym orzeczeniu King's Prosecutor (Brussels) v Cando Armas, [2005] UKHL 67; [2006] 2 A.C. 1 para. 2] podnosi się, że „movement among the member states of the European Union.. to establish, as between themselves, a simpler, quicker, more effective procedure, founded on member states' confidence in the integrity of each other's legal and judicial systems".

Trafnie wskazuje się w literaturze niemieckiej, że zaufanie do obcych przepisów i ich zgodnego z prawem zastosowania, stanowiące dogmatyczną podstawę zasady wzajemnego uznawania, pozwala na jej zastosowanie również w sprawach karnych, por. N. Kotzurek, Gegenseitige Anerkennung und Schutgarantien bei der Europäischen Beweisanordnung, ZIS 2006, s. 126; A. Sakowicz, Zasada ne bis in idem w prawie karnym, Białystok 2011, s. 206-207 oraz podana tam literatura.

M. Cherif Bassiouni, International Extradition: United States: Law and Practice, Nowy Jork 2002, s. 572. 
4. W glosowanym wyroku oraz jego uzasadnieniu Trybunał pominął wypowiedzi, które pojawiły się we wcześniejszych orzeczeniach. Zarówno te, które wskazują, że zasada ne bis in idem „nie znajduje zastosowania do decyzji organów sądowych danego państwa członkowskiego kończących postępowanie bez rozstrzygnięcia merytorycznego w następstwie decyzji prokuratora o zaniechaniu dalszego ścigania karnego wyłącznie z powodu uprzedniego wszczęcia postępowania karnego w innym państwie członkowskim przeciwko temu samemu podejrzanemu za ten sam czyn" ${ }^{21}$, jak i te, które mówią, iż postanowienie o umorzeniu postępowania przygotowawczego i nieprzekazaniu sprawy do sądu orzekającego o odpowiedzialności karnej należy uważać za orzeczenie stanowiące prawomocny wyrok w rozumieniu art. 54 KWUS, stanowiący w konsekwencji przeszkodę dla ponownego ścigania tej samej osoby w odniesieniu do tych samych czynów w innym z umawiających się państw członkowskich $^{22}$.

Co więcej, Trybunał nie dostrzegł, że postanowienie $\mathrm{w}$ fazie in personam o umorzeniu postępowania przygotowawczego z powodu braku wystarczającego materiału dowodowego może zostać wydane przez różne organy oraz posiadać bądź nie posiadać przymiot prawomocności. Wystarczy wskazać np. orzeczenie sędziego śledczego o umorzeniu postępowania z powodu braku dowodów („ordonnance de non-lieu par des raisons de fait" - art. 177 francuskiego kpk.), które nie posiada cechy prawomocności ${ }^{23}$. Wątpliwości są również w przypadku różnych postanowień o umorzeniu postępowania przygotowawczego w Niemczech (zwłaszcza gdy poddamy analizie postanowienie wydane na podstawie $\$ 204$ ust. 1 niemieckiego StPO, określane mianem Nichteröffnungsbeschluss) ${ }^{24}$. Podobnie zresztą rzecz ma się z belgijskim postanowieniem arrêt de de non lieu par des raisons de fait (art. 128 belgijskiego kpk.), które stanowi, że umarza się postępowanie przygotowawcze, gdy w następstwie przekazania sprawy do sądu pierwszej instancji nadzorującej postępowanie przygotowawcze prowadzone przez sędziego okaże się, iż czyn nie stanowi ani zbrodni, ani występku, ani wykroczenia - lub że nie istnieje żaden dowód uprawdopodobniający popełnienie przestępstwa. W przypadku orzeczenia belgijskiego Trybunał w sprawie $M$. zasadnie wskazał, że takie postanowienie zostało wydane co do istoty sprawy oraz ma śnia 2006 r. w sprawie Van Straaten (nr C-150/05), pkt 60; na temat tych orzeczeń zob. szerzej B. Nita, Artykuł 54 konwencji wykonawczej z Schengen w wyrokach Europejskiego Trybunału Sprawiedliwości z 28 września 2006 r., C-467/04, postępowanie karne przeciwko Giuseppe Francesco Gasparini i innym oraz C-150/05, Jean Leon Van Straaten przeciwko Niderlandom i Republice Włoskiej, „Europejski Przegląd Sądowy” 2007, nr 9, s. 4452; A. Sakowicz, Zasada ne bis in idem w prawie karnym, Białystok 2011, s. 384 i n.

22 Wyrok TS z dnia 5 czerwca 2014 r. w sprawie C-398/12 M., Zb. Orz. s. I-1057.

23 F.-F. Bohnert, O. Lagodny, Art. 54 SDÜ im Lichte der nationalen Wiederaufnahmegründe - Zugleich Besprechung von BGH, Urteil vom 10. 6. 1999 - 4 StR 87/98, Neue Zeitschrift für Strafrecht 2000, Heft 12, s. 638-639.

Por. R.M. Kniebühler, Transnationales „ne bis in idem”, s. 238-244; G. Dannecker, Die Garantie des Grundsatzes „ne bis in idem” in Europa, (w:) H.J. Hirsch, J. Wolter, U. Brauns (Hrsg.), Festschrift für Günter Kohlmann zum 70. Geburtstag, Kolonia 2003, s. 608 i n., B. Nita-Światłowska, Prawomocność orzeczenia jako element wyznaczający zakres zasady ne bis in idem w art. 54 Konwencji wykonawczej z Schengen, „Europejski Przegląd Sądowy” 2014, nr 5, s. 28-29; A. Sakowicz, Zasada ne bis in idem w prawie karnym, Białystok 2011, s. 384 i n. 
charakter ostateczny, gdyż powoduje „wygaśnięcie możliwości przedstawienia przez oskarżyciela publicznego aktu oskarżenia na poziomie krajowym" oraz uruchamia zakaz ponownego prowadzenia postępowania karnego wobec tego samego sprawcy o ten sam czyn zabroniony. Wyrażając ten pogląd, Trybunał miał świadomość obowiązywania w systemie belgijskim regulacji prawnych, które pozwalają wznowić postanowienie arrêt de de non lieu par des raisons de fait, jeżeli ujawnią się nowe dowody uprawdopodobniające popełnienie przestępstwa (art. 246-248 belgijskiego kpk.). Trybunał w tej sprawie wyraźnie bowiem wskazał, że „możliwość wznowienia postępowania przygotowawczego prowadzonego przez sędziego z powodu ujawnienia się nowych dowodów uprawdopodobniających popełnienie przestępstwa (...) nie może podać $\mathrm{w}$ wątpliwość prawomocnego charakteru postanowienia o umorzeniu postępowania przygotowawczego rozpatrywanego w postępowaniu głównym. Wprawdzie owa możliwość nie stanowi „nadzwyczajnego środka odwoławczego" w rozumieniu rzeczonego orzecznictwa Europejskiego Trybunału Praw Człowieka, ale zakłada ona wszczęcie w drodze wyjątku - i to na podstawie innych dowodów - raczej odrębnego postępowania niż zwykłej kontynuacji już zamkniętego postępowania. Ponadto, biorąc pod uwagę konieczność weryfikacji prawdziwie nowego charakteru dowodów powołanych w celu uzasadnienia wznowienia postępowania, każde nowe postępowanie oparte na takiej możliwości wznowienia, przeciwko tej samej osobie i w odniesieniu do tych samych czynów, może być wszczęte wyłącznie w umawiającym się państwie, w którym wydano owo postanowienie"25. Uważam, że takie stanowisko jest zgodne $\mathrm{z}$ istotą zasady ne bis in idem oraz mechanizmami współpracy $\mathrm{w}$ sprawach karnych na obszarze UE. Stąd wykładnia przepisu art. 54 Konwencji Wykonawczej powinna być dokonana w zakresie przedmiotu i celu tego przepisu, a także z zamiarem zapewnienia zasadzie ne bis in idem właściwej efektywności (proper effect), a nie $\mathrm{w}$ celu interpretacji formalnych przepisów proceduralnych państw członkowskich, które nie mają charakteru niejednorodnego, jeżeli weźmiemy pod uwagę poszczególne systemy prawne.

Kończąc warto wskazać, że podobna wątpliwość pojawia się na podstawie polskiego kpk., tj. gdy zostanie wydane postanowienie o odmowie wszczęcia lub o umorzeniu postępowania $\mathrm{z}$ uwagi na brak danych dostatecznie uzasadniających podejrzenie popełnienia przestępstwa (art. $17 \$ 1$ pkt $1 \mathrm{kpk}$.). Trzeba jednak zauważyć, że postanowienie takie uzyskuje walor prawomocności materialnej, gdy bezskutecznie upłynął termin do jego zaskarżenia, względnie gdy wyczerpany został tok kontroli instancyjnej. Nie znosi waloru prawomocności możliwość wzruszenia go w sytuacji nadzwyczajnej, tj. po spełnieniu przesłanek wskazanych w art. $327 \$ 2 \mathrm{kpk}$. Jest to bowiem sytuacja wyjątkowa. Co więcej, wyjątkowość tej sytuacji przedstawia się odmiennie w zależności od tego, kto podjął decyzję o umorzeniu postępowania przygotowawczego z braku dowodów, tj. czy prokurator, czy sąd przed 
otwarciem przewodu sądowego (art. $339 \$ 3$ pkt 2 kpk.). W pierwszej sytuacji nowe istotne fakty lub dowody nieznane w poprzednim postępowaniu mogą stanowić podstawę dalszego prowadzenia postępowania przygotowawczego, gdy zaś prawomocne umorzenie postępowania przez sąd nie może spowodować wznowienia postępowania karnego na niekorzyść oskarżonego. Różnica ta, wynikająca z naszego systemu prawnego, nie może ani ograniczać funkcjonowania zasady ne bis in idem na obszarze państw członkowskich, ani odmiennie zabezpieczać pewności sytuacji prawnej jednostki, gdyż w przypadku obu rozstrzygnięć mamy do czynienia $\mathrm{z}$ orzeczeniami prawomocnymi oraz wydanymi co do istoty sprawy ${ }^{26}$. Wiadomym jest też - od wyroku w sprawach połączonych Gözütok i Brügge - że zasadę ne bis in idem wyrażoną w art. 54 KWUS stosuje się również do postępowań prokuratora podejmowanych bez udziału sądu, kończy definitywnie postępowanie karne, zatem forma orzeczenia oraz jego pochodzenie od określonego organu procesowego nie mają znaczenia rozstrzygającego dla zakresu analizowanej zasady ${ }^{27}$.

26 Odmiennie M. Wąsek-Wiaderek, Prawomocne umorzenie postępowania przygotowawczego jako rozstrzygnięcie kreujące zakaz ne bis in idem w Unii Europejskiej, (w:) M. Sitarz, P. Stanisz, H. Stawniak (red.), Reddite ergo quae sunt Caesaris Caesari et quae sunt Dei Deo. Studia in honorem Prof. Josephi Krukowski Dedicata, Lublin 2014, s. 908-909.

27 Tak też B. Nita-Światłowska, Prawomocność orzeczenia jako element wyznaczający zakres zasady ne bis in idem w art. 54 Konwencji wykonawczej z Schengen, „Europejski Przegląd Sądowy” 2014, nr 5, s. 30. 